\title{
プラスチックピグメント添加による白紙光沢発現の機構解析
}

\author{
三井東圧化学株高分子研究所 星野 太, 媣谷将世, 柳原 壯

\section{Mechanism analysis of sheet gloss development by addition of plastic pigment}

\author{
F. Hoshino, S. Fukaya and T. Yanagihara \\ Mitsui Toatsu Chemicals, Inc.
}

\begin{abstract}
Effects of the particle size of plastic pigment on sheet gloss and structure of coatings which were constituted of clay/plastic pigment/binder were studied. The most effective particle size for sheet gloss was about $200 \mathrm{~nm}$ and the ranking of the size for sheet gloss did not vary before and after supercalendering. In addition, such ranking was not affected by the king of binder coexisted in coating.

From structural analysis, it was found that the coating having highest sheet gloss showed highest degree of orientation of clay particles, highest surface smoothness in submicron range, and lowest surface concentration of plastic pigment.

Those results indicated that clay/plastic pigment packing manner, which would affect the orientation of clay particles and the surface smoothness, was a dominant factor for sheet gloss development rather than thermoplasticity of plastic pigment.
\end{abstract}

\section{1.はじめに}

近年，高分子化合物からなる有機微粒子，即ちプラ スチックピグメント (以下, PP と略す) が主に白紙光 沢を向上させる目的からクレーや炭酸カルシウムなど 無機顔料の一部を置き換えて使用される傾向が増して いる。ここで PP 添加による効果としては，上記白紙光 沢をはじめ白色度, 白紙不透明度, インク受理性など の向上，および軽量化を挙げることができ1)，これまで に種々報告がなされている。

上記, PP の特性で光散乱特性については理論的に もかなり明確な報告がなされているが2),3), 最も重要な 特性である白紙光沢の発現については, (1) PP の熱可 塑性によるカレンダー効果の增大 ${ }^{4)}$, (2)顔料充塡構造 の変化による表面平滑性の向上5)であるという報告が なされているものの明確にはなっていないと思われる。 本報では粒子径の異なる 6 種のポリスチレン粒子を PP とし, 白紙光沢および塗工層の構造に及ぼす PP 粒 子径の影響を評洒し，その結果よりPP添加による白 紙光沢発現の機構を推測した。

平成 4 年度年次大会 (紀伊勝浦)において発表した。

\section{2. 実験}

PP としては乳化重合によって調製した粒子径が 77, 125，170，479，748，941 nmの 6 種類のポリスチレン 製の密実型粒子を使用した。

塗工液の配合を表 1 に示す。塗工は自動塗工機でア プリケーターバーを用いて行った。なお塗工後の乾燥 は $120^{\circ} \mathrm{C} ， 20$ 秒とした。

\section{3. 結果および考察}

\section{1 白紙光沢に及ぼす $\mathrm{PP}$ 粒子径の影響}

先ず，上質原紙 $\left(66.5 \mathrm{~g} / \mathrm{m}^{2}\right)$ 上に下記塗工液を叙布

表 1 塗工液配合

\begin{tabular}{l|c}
\hline \multicolumn{1}{c|}{ 成 } & 重量部数 \\
\hline クレー(UW 90) & 90 \\
$\mathrm{PP}$ & 10 \\
分散剂（アロン T-40) & 0.25 \\
SBR ラテックス & 12 \\
リン酸エステル化澱粉 (MS 4600) & 3 \\
\hline 叙料固形分 & $60 \%$
\end{tabular}




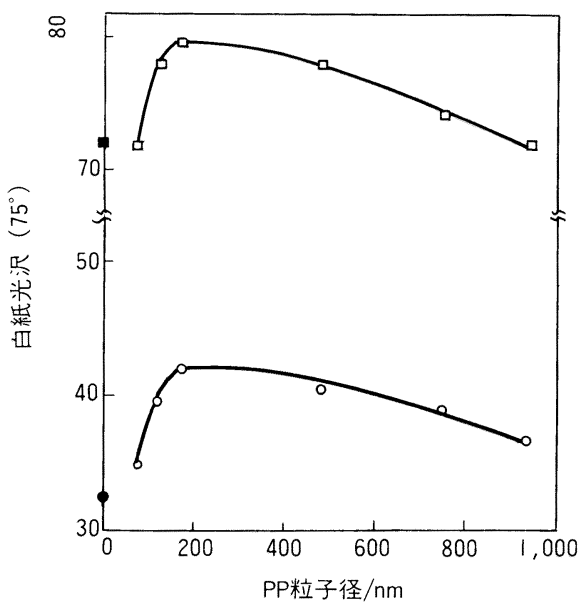

図 1 白紙光沢に及ぼす PP 粒子径の影響 $\mathrm{UW} 90 / \mathrm{PP}=90 / 10$, 塗工量 $: 12 \mathrm{~g} / \mathrm{m}^{2}$ (上質紙)

$\bigcirc: \mathrm{PP}$ 添加系, カレンダー無し

: UW 90 単独系, カレンダー無し

$\square$ : PP 添加系, カレンダー有り $\left(60^{\circ} \times 100 \mathrm{~kg} /\right.$ $\mathrm{cm}, 2$ 回)

口 : UW 90 単独系, カレンダー有り（同上）

し，カンレンダー処理を行った場合 $\left(60^{\circ} \mathrm{C} \times 100 \mathrm{~kg} /\right.$ $\mathrm{cm}, 2$ 回通紙）と行わなかった場合の白紙光沢の值を 図 1 に示す。図 1 より白紙光沢はPP の粒子径が 170 $\mathrm{nm}$ で最大となる曲線を示し, これは $200 \mathrm{~nm}$ 付近で白 紙光沢が最も高くなるとした既報 ${ }^{6)}$ と同様なもので あった。また, その白紙光沢一PP 粒子径の関係はカレ ンダー処理の有無によって変化することはなく, カレ ンダー処理による白紙光沢の向上率はPP 無添加系の 方が大きいという結果を得た。

以上の結果は, PP 添加することによる白紙光沢 向上の主要因が PP の熱可塑性によるカレンダー効果 の増大ではないことを示唆している。

上記の結果を踏まえ, 以下の塗工は全て PET フィ ルム（ルミラーS 100 ：パナック(株製）を使用し，カレ ンダー処理を行わない条件で各種の測定, 分析を行っ た。

図 2 に再度 PETフィルム上に塗布した時（塗工 量：12 および $22 \mathrm{~g} / \mathrm{m}^{2}$ ) の白紙光沢を示す。図 2 の結 果は塗工量により曲線の形が若干変化するものの, 上 質紙に塗工した図 1 と同様な白紙光沢一PP 粒子径の 関係を示した。

図 3 には無機顔料を一切含まない PP/SBR ラテッ クス $=100 / 50$ の時の白紙光沢の值を示す。この系では 白紙光沢は PP の粒子径が小さくなるに従ってその值

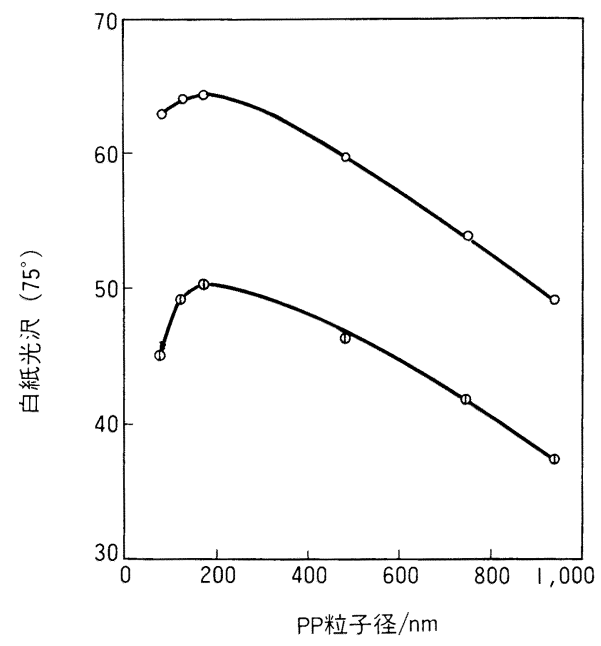

図 2 白紙光沢に及ぼす PP 粒子径の影響 $\mathrm{UW} 90 / \mathrm{PP}=90 / 10$

塗工量：(1): $12 \mathrm{~g} / \mathrm{m}^{2}, \bigcirc: 22 \mathrm{~g} / \mathrm{m}^{2}$ (PET)

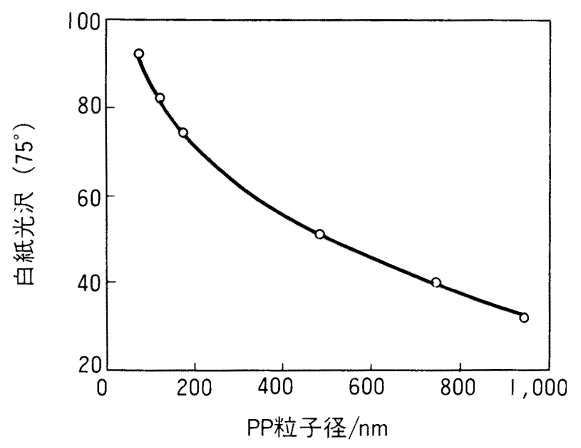

図 $3 \mathrm{PP}$ 単独使用時の白紙光沢 $\mathrm{PP} / \mathrm{SB}$ latex $=100 / 50$, 塗工量 : $30 \mathrm{~g} / \mathrm{m}^{2}$

が大きくなる傾向を示した。

図 2 および図 3 の結果より, PP 添加による白紙光 沢発現は無機顔料と PP との相互作用に依存すること を示唆していると考えられる。

\section{2 塗工層の構造解析}

白紙光沢が PP の粒子径に依存する原因を解析する ため, 図 2 の塗工量 $22 \mathrm{~g} / \mathrm{m}^{2}$ の塗工層を用い, 以下の 3 項目の測定からその構造解析を試みた。

1）塗工層の表面 PP 濃度

塗工層表面への PP のマイグレーション, 即ち塗工 層中での PP の分布状態と白紙光沢との相関を検討す る目的で表面のPP 濃度を測定した。

測定は(株)島津製作所製コート紙表面分析システム 


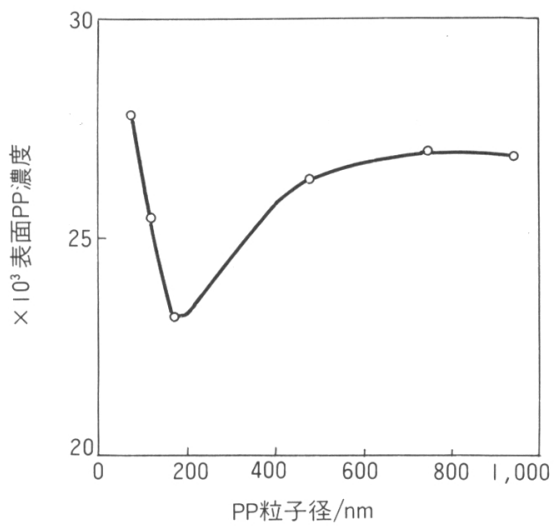

図 4 表面 PP 濃度の粒子径による变化

CS 9000 C を用い，スチレンのベンゼン環由来の 260 $\mathrm{nm}$ の UV 吸収より濃度を求めた。なお SBR ラテック スに由来する吸収を消去するため，PP を含有しない 系の塗工層表面から求植を差し引くことにより $\mathrm{PP}$ 由来の吸収を求めた。結果を図 4 に示す。

図 4 より PP の表面濃度と白紙光沢は非常に良い相 関を示し, 白紙光沢が最大であった $170 \mathrm{~nm}$ の系で PP の表面濃度が最低となった。

この結果は PP が塗工層表面にマイグレートせずに 均一に分布していることが白紙光沢発現の因子になる ことを示浗しているものと考えられる。

2）塗工層の表面モルフォロジー

白紙光沢発現に大きく影響を及ぼすと考えられる塗 工層表面のモルフォロジー（幾何学的凹凸度）につき， (森エリオニクス社製のトポグラフィック SEM（ERA -8000）を使用して塗工層表面の中心線平均粗さ $\mathrm{Ra}$ を 測定した。表 2 に測定条件を示す。

測定はサンプルを変えて 3 回行い，図 5 に示すよう な表面の幾何学的凹凸度の測定チャートよりコン ピューター計算で中心線平均粗さ $\mathrm{Ra}$ を算出した。結 果を図6 に示す。

図6の結果は白紙光沢の結果と非常に良い一致を示 しており，白紙光沢が最大となった粒子径 $170 \mathrm{~nm} の$ 系で最も高い幾何学的な平滑性を示した。以上の結果

表 2 表面モルフォロジー測定条件

\begin{tabular}{l|c}
\hline SEM 倍率 & 10,000 倍 \\
ビーム直径 & $15 \mathrm{~nm}$ \\
測定領域 & $12,000 \times 9,000(\mathrm{~nm})$ \\
測定スポット間隔 & $50 \mathrm{~nm}$ \\
測定スポット数 & 43,200 点 \\
\hline
\end{tabular}

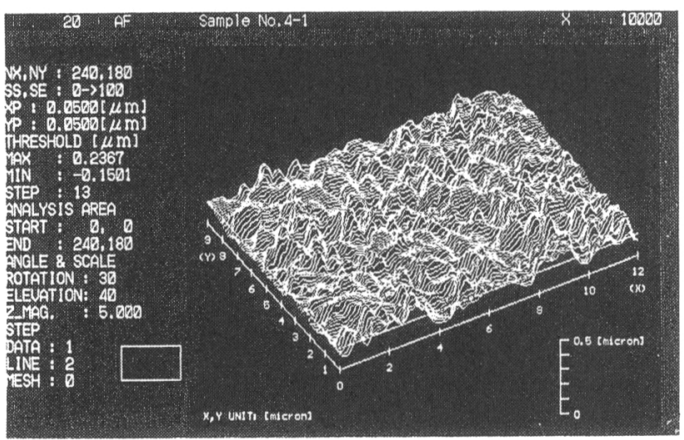

図 5 表面モルフォロジー測定チャート

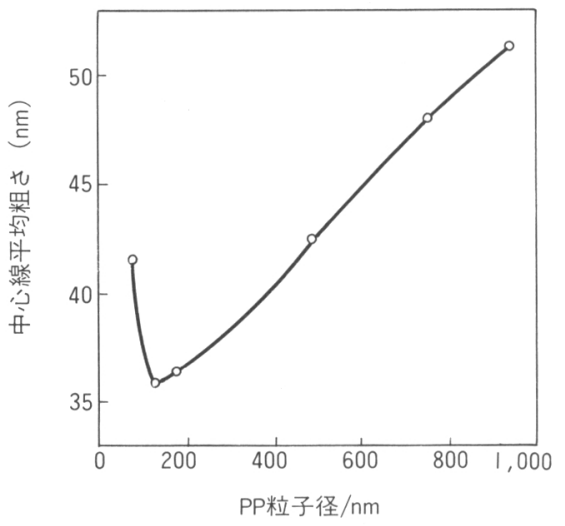

図 6 表面平滑性に及ぼす PP 粒子径の影響

よりトポグラフィックSEM を用いて測定した微小 領域での凹凸度, 即ち平滑性が白紙光沢を決定してい ることが確認された。

3）クレーの配向度合い

白紙光沢とクレ一配向の相関を検討する目的で，既 報7)に基づき $\mathrm{X}$ 線回折法 (オフセット法)によりクレー の配向状態を測定した。なお配向状態を明確に測定す る目的から，サンプルは表 1 に示したUW 90 をより 燐片状のコマルコカオリンに変えて作製したものを用 いた。ここで白紙光沢と PP 粒子径の関係は UW 90 の 場合と同様であった。

測定は $2 \theta=37.7^{\circ}$ 付近の (003) 面を対象面とし，才 フセット角度 $\alpha=0^{\circ}, 3^{\circ}, 6^{\circ}, 9^{\circ}$ の 4 点測定から強度の 減少率を算出した。結果を図 7 に示す。

図 7 よりクレーの配向度合いと白紙光沢は非常に良 い相関を示し，白紙光沢が最大であった $170 \mathrm{~nm} の$ 系 でクレーの強度減少率が最大, 即ち配向度合いが最大 であった。

\subsection{PP 添加による白紙光沢発現機構}

以上の結果のみから PP 添加による白紙光沢発現機 


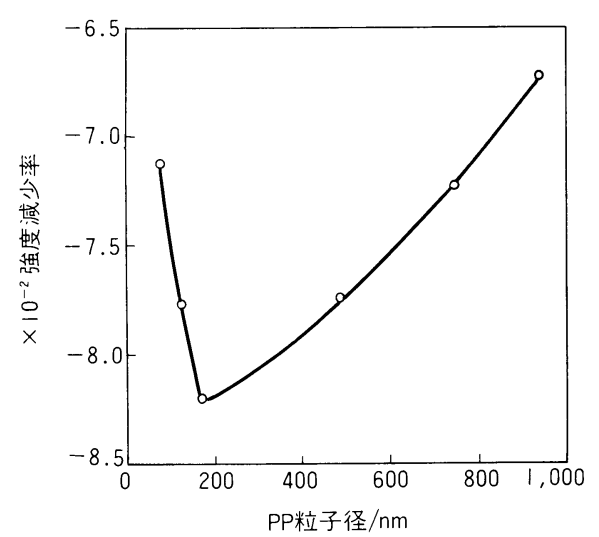

図 7 クレーの配向に及ぼす PP 粒子径の影響

構を断定することは困難ではあるが，本報告の系の場 合, 従来考えられていたPP 自体の熱可塑性によるカ レンダー効果の増大ではなく, PP とクレーの相互作 用が重要な因子であり，塗工層内で両者が均一に分布 し，クレーの配向が向上するために表面の微視的な平 滑性が向上し，白紙光沢が発現したものと推測される。
ここで, $\mathrm{PP}$ はクレーのミクロな分散を向上させ, 配向 状態をよりとり易くするなめの, 所謂,「コロ」の役目 を果たしているとも考えられる。

最後に塗工層の表面モルフォロジー測定に多大なる 御協力を頂いた侏エリオニクス社に感謝申し上げます。

\section{参考文献}

1）浜口, 紙パルプ技術協会平成 2 年度年次大会講演 要旨集, p 81

2) J. Borch and P. Lepoutre, Tappi, 61 (2), 45 (1978)

3) B. Alince and P. Lepoutre, J. Colloid \& Interface Sci., 76, 182 (1980)

4) E. J. Heiser and A. Shand, Tappi, 56 ( 1), 70 (1973)

5) B. Alince and P. Lepoutre, Tappi, 63 ( 5 ), 49 (1980)

6) E. H. Rossin, PULP \& PAPER, June, 57 (1974)

7) D. J. Kraske, Tappi, 43 ( 1 ), 73 (1960) 